\title{
Art and megafauna in the Top End of the Northern Territory, Australia: Illusion or reality?
}

\author{
Paul S.C. Taçon and Steve Webb
}

\section{Introduction}

The term 'megafauna' is used to describe 'an arbitrary compilation of relatively large mammalian, reptilian, and avian taxa, ranging in size from $-10 \mathrm{~kg}$ or less up to $>2,000 \mathrm{~kg}$ ' (Wroe et al. 2013a:8777). In Australia, there were over 50 species in at least six genera commonly discussed as becoming extinct since the arrival of modern humans about 50,000 years ago (for a detailed summary see Cane 2013:41-47); however, within a broader time frame, 88 taxa disappeared over the past 450,000 years (Webb 2013; Wroe et al. 2013a, 2013b).

Across the world, megafauna have long fascinated artists and scientists alike, as evidenced by European Upper Palaeolithic rock art and over 100 years of global palaeontological research, as well as fierce debates between scientists about regional- to continental-scale causes of megafaunal extinctions. The role of humans in Pleistocene megafaunal extinctions is a key question long debated in Europe, North America and Australia. Human predation in blitzkrieg fashion versus slower human-induced versus climate change-induced causes are the polemics, with contemporary debate being particularly fierce in Australia (e.g. Brook et al. 2013; Johnson 2006; Miller et al. 1999; Roberts et al. 2001; Webb 2013; Wroe and Field 2006; Wroe et al. 2004, 2006, 2013a, 2013b). However, 'a paucity of empirical data; shortfalls in radiometric dating; and, until recently, a limited appreciation of the paleoenvironmental record have placed considerable constraints on the ability to resolve "who" or "what" was responsible for these extinctions' (Wroe et al. 2013a:8777). A related debate in Australia focuses on whether Aboriginal people made depictions of Pleistocene megafauna at rock art sites and, if they did, whether such art survives. As with causes of extinction, there are extreme views varying from full acceptance that there are surviving rock art depictions of megafauna (e.g. Cane 2013) to full rejection (e.g. Bednarik 2013a; Lewis 2017).

\section{Megafauna in the Australian landscape}

The patchy fossil record in Australia is one of the main problems that limits resolution of the extinction debate (Wroe et al. 2013b), but also coarse-grained excavation techniques and problems of mixing of sediments at some sites. For instance, a recent continental survey of late Quaternary fossil megafauna in Greater Australia suggests most species lived in south-central, 
southeastern and eastern coastal areas (Webb 2008, 2013). Few species have been recovered from Australia's arid regions where only one or two individual bones have been found and large areas of desert have no evidence for them. Another region that has lacked remains is the Top End of the Northern Territory. The discovery of remains of a single Diprotodon sp. in 2012 on Auvergne Station in the Northern Territory is the one exception, although it remains undated. Nevertheless, one conclusion is that megafauna did not live in deserts, other than perhaps Genyornis. But their rarity in the Top End is puzzling because varied species occupied diverse environments elsewhere across the southern part of the continent. Australia's north probably offered a good occupational environment for megafauna even during glacial maxima, given their distribution elsewhere. Consequently, poor adaptation to a tropical environment among the full range of megafaunal species does not seem likely. Furthermore, it is probable that bone preservation in the north has not been as good as in other parts of the continent, partly due to the acidic nature of the soils. Also, much of the north has unsuitable sediments for bone preservation, and wet tropical, closed forest conditions over the past 15,000 years or so have promoted destruction and poor preservation as well as making the finding of fossil bone today difficult. Limited exposure of suitably aged sediments is likely to be another reason for the absence of fossil evidence. But the problem of missing megafauna and its survival into more recent times than previously argued may be more apparent than real, as suggested by rock paintings from the north of Australia.

\section{Rock art depictions and problems of interpretation}

Research over the past 30 years has shown that evidence for megafauna in northern Australia may come from rock art. Australia has more rock art sites than any other country, and most of these sites are scattered across the north (Taçon 2011). A growing archive of curious images in rock art galleries located in the Pilbara, Kimberley, Kakadu and broader Arnhem Land regions have long caught the attention of rock art specialists, archaeologists and palaeontologists (Akerman 1998, 2009; Akerman and Willing 2009; Brandl 1972; Chaloupka, 1993; Clegg 1978; Gunn et al. 2011; Mulvaney 2009, 2013; Murray and Chaloupka 1984; Ouzman et al. 2002; Walsh 2000). Some images have prompted their consideration as depictions of extinct animals and initiated serious analysis of their form, size and representation. Initially, one or two images were tentatively identified as unusual animals and then as possibly extinct megafauna (see Murray and Chaloupka 1984). The thylacine or Tasmanian tiger (Thylacinus cynocephalus) and Tasmanian devil (Sarcophilus harrisii) are two extinct animals so identified (Lewis 1977, 1988; Taçon et al. 2011). These latter two species became extinct on the Australian mainland c. 4000 years ago and c. 3000 years ago, respectively (Archer 1974; Brown 2006; Gollan 1984; note that Brown 2006 rejects a suggested age of c. 430 years ago for the extinction of the Tasmanian devil). While such images are interesting, neither species can be regarded as megafauna because of their small size and, although they may be very old, they survived well into the mid to late Holocene. Other depictions arguably include the long-nosed echidna (Zaglossus bruijnii), now only resident in New Guinea (Chaloupka 1993). Paintings of Zaglossus are - like the thylacine with its dog-like body and stripes and the Tasmanian devil - distinct and unmistakable, because of the long, slim nose and distinctive echidna body shape. But in the rock art there are other images of much larger and unknown animals painted in a realistic manner, prompting their identification as megafauna. These images of large fauna are single examples, stirring not only a reassessment of the geographical distribution of megafauna, but also the timing of their extinction and/or the age of the art itself.

Reports of megafauna in Australian Aboriginal rock art go back to the early 20th century (Basedow 1925). Recent examples include one of two species of large herbivores, Palorchestes parvus or P. azeal (Chaloupka 1993; Murray and Chaloupka 1984), the giant flightless bird 
Genyornis newtoni (Gunn et al. 2011; Ouzman et al. 2002; Trezise 1971) and the marsupial lion Thylacoleo carnifex (Akerman 1988, 2009; Akerman and Willing 2009; Wright 1972). All identifications are made with a great deal of caution, particularly because none have been dated and variable image preservation caused by weathering, water action, discolouration, mineral staining, over-painting, erosion or exfoliation of the rock surface.

Nevertheless, likely megafauna images depict an enigmatic creature whose morphology contrasts with known taxa in the region or anywhere on the continent; these are readily identified as something 'odd'. Informed Aboriginal Elders agree with this (e.g. see Chaloupka 1993:100). However, a problem is that we lack many details of exactly what megafauna species looked like, and usually depend on informed reconstructions based on fossil skeletal remains. Reconstructions are never precise in terms of the exact shape of the body. Furthermore, reconstructions do not account for natural body form variation, sexual dimorphism and other forms of minor or even major morphological variation, such as soft tissue details. On the other hand, rock art images can include hair type, coat colour, fur thickness and length as well as details such as spots, stripes, ear and rhinarium shape, tail shape, thickness and length, and other body details. Because of this, rock art images may contain unusual or equivocal features that are hard to identify or attribute from fossil reconstructions, even though in the art they may be naturalistic depictions of a living animal. Consequently, an animal depiction may not be securely identified, and Bednarik (2013a) takes the view that there are no strong identifications at all.

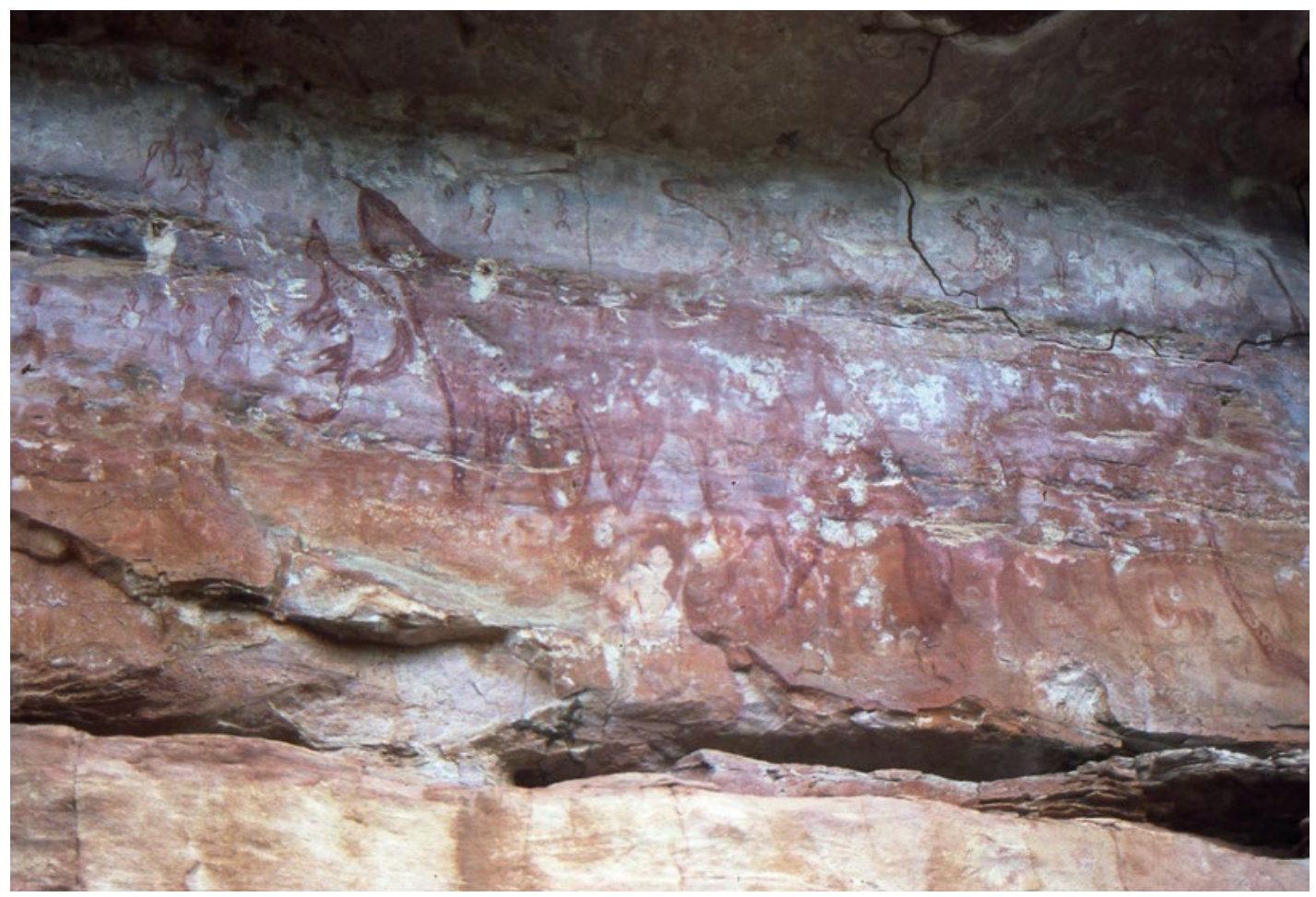

Figure 8.1 The painting of the megafauna species Palorchestes that displays two prominent tufts of chest hair and is accompanied by a smaller (younger?) version of the same animal.

Source: Photograph by Paul S.C. Taçon.

To illustrate this problem of uncertainty in interpretation, an image of a large animal at a site east of Nauwalabila in Deaf Adder Gorge, western Arnhem Land (Figure 1.1), shows a quadruped with muscular limbs, a long tongue, prominent claws, a long narrowing face, a coarse coat, robust legs and thick hair covering a thick tail. This image also has two bulky 'tufts' of chest hair or something similar (Figure 8.1). At its anterior end, there is a smaller version of the same 
creature that may or may not be a young animal. This smaller animal also has very prominent claws on its front feet. Both creatures have spotted coats and a mane extending from the head to the base of the tail. The appearance of the animals is consistent with expectations of a $350 \mathrm{~kg}$ Palorchestes, a genus of megafauna thought to have a short, trunk-like rhinarium and strong arms with large claws for ripping bark from trees and dead wood while searching for termites. This particular rock painting scene has indeed been identified as Palorchestes by some researchers, although the two images have not been allocated a species name (P. parvus or P. azeal) (Murray and Chaloupka 1984). It is difficult to explain the two tufts hanging from the larger creature's chest but, whatever they are, the smaller animal also has them. The larger of the two paintings is several metres long, suggesting that the large size is itself a naturalistic representation of a very large animal.

There were only three genera of large quadrupeds - all diprotodontids - that were possibly living at the time of early human occupation in Australia. They consist of Diprotodon optatum, Zygomaturus trilobus and the two species of Palorchestes. The distinctive form of Diprotodon does not fit the image of the two Palorchestes-like creatures discussed above, and Zygomaturus had prominent, laterally flared cheek bones, surely something an artist would depict and these are not shown on the rock paintings. Thus, the only animal whose gross morphology fits the image is Palorchestes, and that has also been the conclusion of others (Chaloupka 1993; Murray and Chaloupka 1994). There is another possibility, of course: the image is not one of a living fleshand-blood taxon but a spiritual creature or Ancestral Being (Ouzman et al. 2002). For instance, Bednarik (2013a:204) argues it is not naturalistic, while others such as Welch and Welch (2015) and Lewis (2017:95) contend it is likely a depiction of a mythical creature. However, the painting's close resemblance to present fossil reconstructions of Palorchestes lends support to that interpretation.

Below we present new evidence of four large depictions of strange animals unlike any extant in recent times, in order to elucidate debates about 1) whether Aboriginal people made pictures of megafauna; 2) the durability of rock art; 3) megafauna distribution; and 4) the nature of extinctions.

\section{New discoveries}

\section{Thylacoleo in the Kimberley and Arnhem Land?}

As already noted above, it has been suggested that some rock art images represent Thylacoleo in Arnhem Land (Murray and Chaloupka 1984) and the Kimberley (Akerman 1988, 2009; Akerman and Willing 2009; Wright 1992; although paintings reported by Akerman are more thylacine-like than Thylacoleo - see Lewis 2017; Taçon et al. 2011; Welch 2015). Another image is reported here, located during survey and recorded by one of us (PT) at the Djulirri rock art complex in the Wellington Range, northwest Arnhem Land (Figure 8.2). There were only two now-extinct dog-shaped quadrupeds that lived in Greater Australia during the past 60,000 years: thylacine and Thylacoleo. The difference between the two is obvious from their respective skeletons, particularly their individual head shapes. Thylacoleo had a large, robust jaw structure totally unlike that of the thylacine, which was much smaller. Also unlike the thylacine, Thylacoleo had prominent paws and claws, as well as strong front limbs. In the Kimberley painting reported by Akerman (1988, 2009; Akerman and Willing 2009), the front paws and claws are emphasised, unlike depictions of thylacines that have comparatively delicate dog-like front paws. 


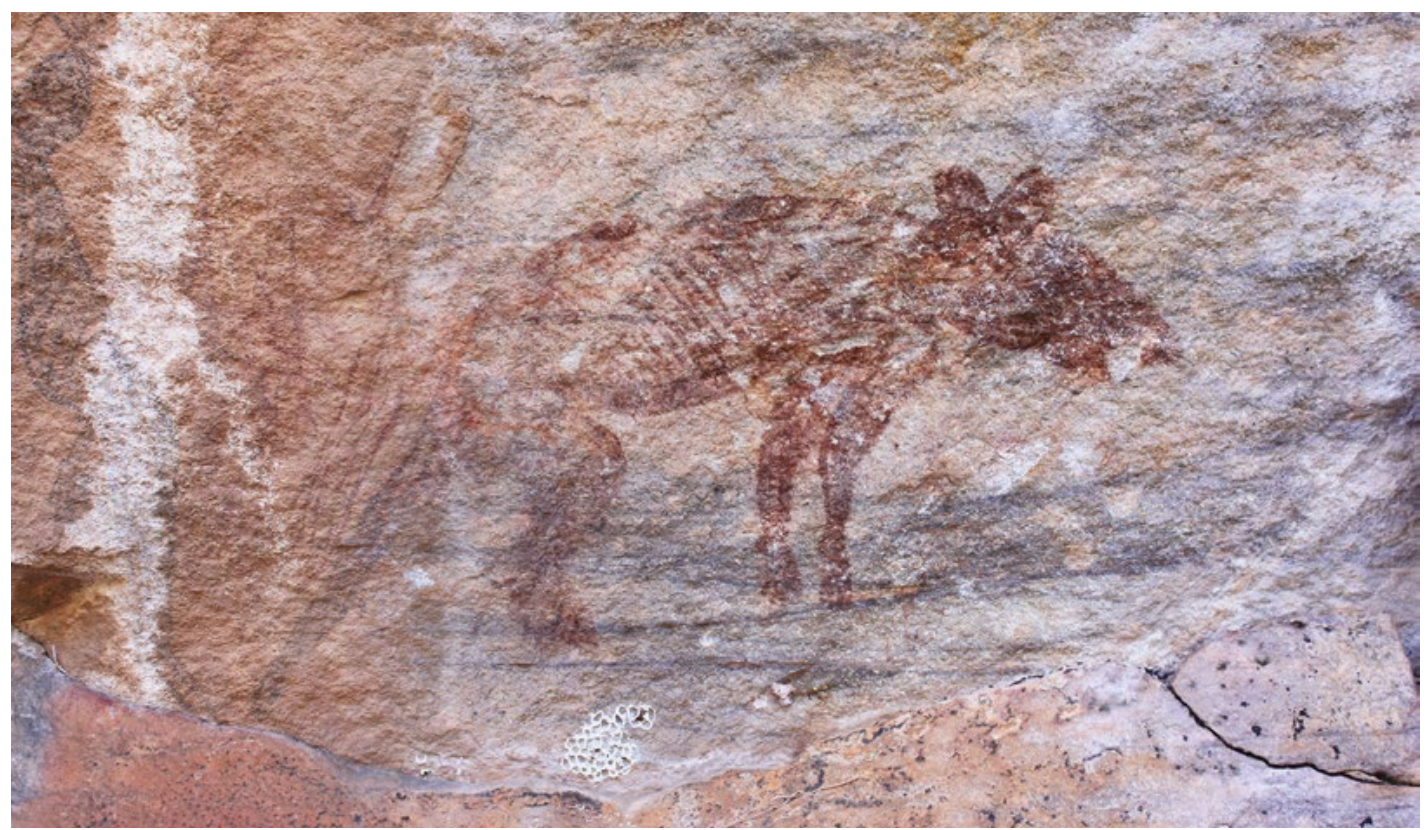

Figure 8.2 This painting depicts a predatory quadruped with a distinctively developed head and muzzle region unlike a thylacine. It is suggested that the robust proportions of the head represent a morphology similar to that of the marsupial lion Thylacoleo carnifex.

Source: Photograph by Paul S.C. Taçon.

The recently discovered northwest Arnhem Land painting measures $91 \mathrm{~cm}$ long by $46 \mathrm{~cm}$ high, smaller than an actual life-size Thylacoleo, but with a proportionally large head $28 \mathrm{~cm}$ long by $11 \mathrm{~cm}$ high, again quite unlike that of an actual thylacine and numerous Arnhem Land rock paintings of thylacines (e.g. see Taçon et al. 2011). The new painting is larger than that of most thylacine paintings, with a deeper, thicker muzzle and robust jaw; cranial features Thylacoleo-like but unlike those of the thylacine. However, the front legs and paws are smaller than those of the Kimberley paintings suggested to be of Kimberley Thylacoleo and the build of the legs is somewhat gracile - unlike that expected of a $150 \mathrm{~kg}$ Thylacoleo - although the back legs are robustly constructed. The Arnhem Land painting also lacks the distinctive stripes on the rear half of the body almost always painted in thylacine depictions, having instead a mix of diagonal and horizontal infill along with patches of solid or no infill as is typical of the oldest animal paintings. Lewis (2017) has not been to the site but made a drawing from a supplied photograph. His suggestion of stripes (2017:94) is not consistent with the clearly striped thylacine-like paintings documented elsewhere. Furthermore, his drawing (2017:93) has a longer overall head than the actual painted animal.

How do we explain the unusual mix of features in this painting? It appears that the animal image was repainted at least once, with a smaller more thylacine-like animal (with the diagonal lines and larger head) painted over the original more Thylacoleo-like animal. Rock paintings were often painted over in Arnhem Land (e.g. see example of overlapping thylacine images in different styles in Taçon et al. 2011) and many layers of painting are found at numerous sites. Perhaps the more recent image of a thylacine-like depiction was added after Thylacoleo became extinct and the painting was 'updated' to suit the environment of the second artist. For instance, there is a very recent example of this phenomenon with a painting of a European tall ship later repainted with a smoke stack to turn it into a steamer (May et al. 2013:91-94). The original possible Thylacoleo-to-thylacine image is more of a dark-red stain in the rock, while the second and more recent animal is slightly lighter in colour and has a longer snout. At the very least, the Arnhem Land animal depiction is not of an extant species, nor is it a representation of the more gracile thylacine. Exactly what was originally depicted remains to be resolved. 


\section{Procoptodon in Arnhem Land?}

Animal images made by ancient artists at other sites also provide probable identification as depictions of megafauna. One of these is in the Ubirr rock art complex in the north of Kakadu National Park. It is the largest image in a multi-layered complex of paintings spanning the width of a gallery that fills a small rockshelter. Although known for decades, this panel was not comprehensively studied until the site was visited in 2012 (by SW). While partially masked by more recent art, the image of interest here shows an outline of an extremely large and wellmuscled macropod measuring $235 \mathrm{~cm}$ long by $185 \mathrm{~cm}$ high (Figure 8.3). The artist has used short paint strokes in the outline, perhaps to depict coarse fur while also showing hairy ears. The tail has a thick base and remains stout along its entire length, unlike modern kangaroo tails and indicative of an appendage required to support a large, heavy body when sitting upright (Figure 8.4). The testes placed just below the base of the tail indicate a male animal, a detail the artist must have felt necessary to include. The legs are well-muscled, strong and end at a partially lifted foot with circular designs emphasising the ankle at the tarsometatarsal joint. The foot terminates in a single, large claw (Figure 8.5). The distinctive feature of this kangaroo painting, however, is its short face with rounded muzzle. Although the face is somewhat faded distally, close inspection and the tracing of lines from the brow shows the rounded form and shortened facial morphology (Figure 8.6).
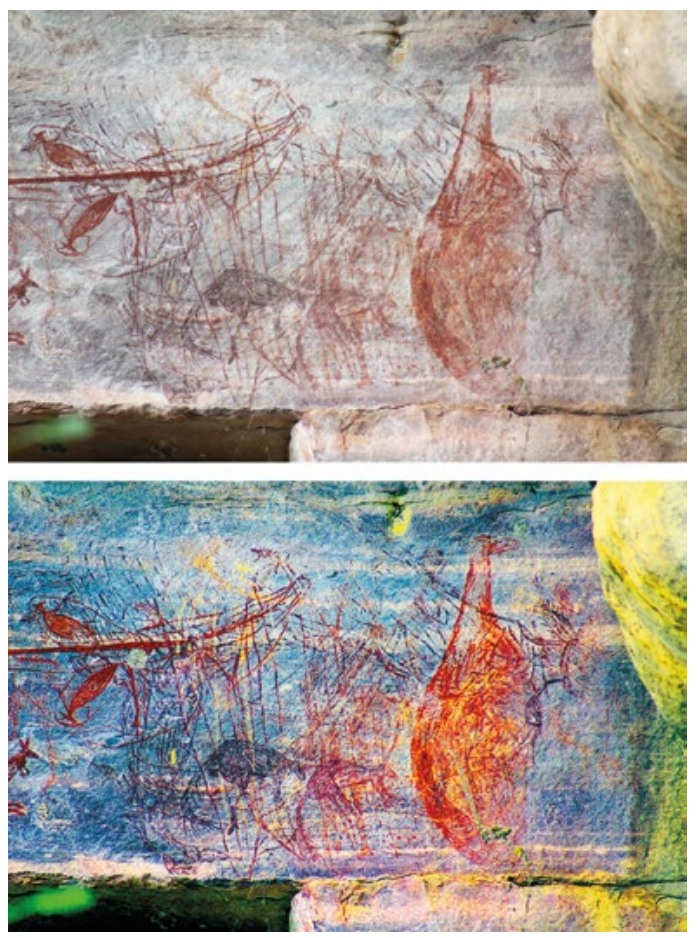

Figure 8.3 Top: An image of the large, shortfaced kangaroo painted in life-like proportions in Kakadu National Park. Bottom: Enhanced image using DStretch. Note the large claw, thick tail and short face of the animal. The large flightless bird mentioned in the text is also plainly visible.

Source: Photograph and enhancement by Steve Webb.
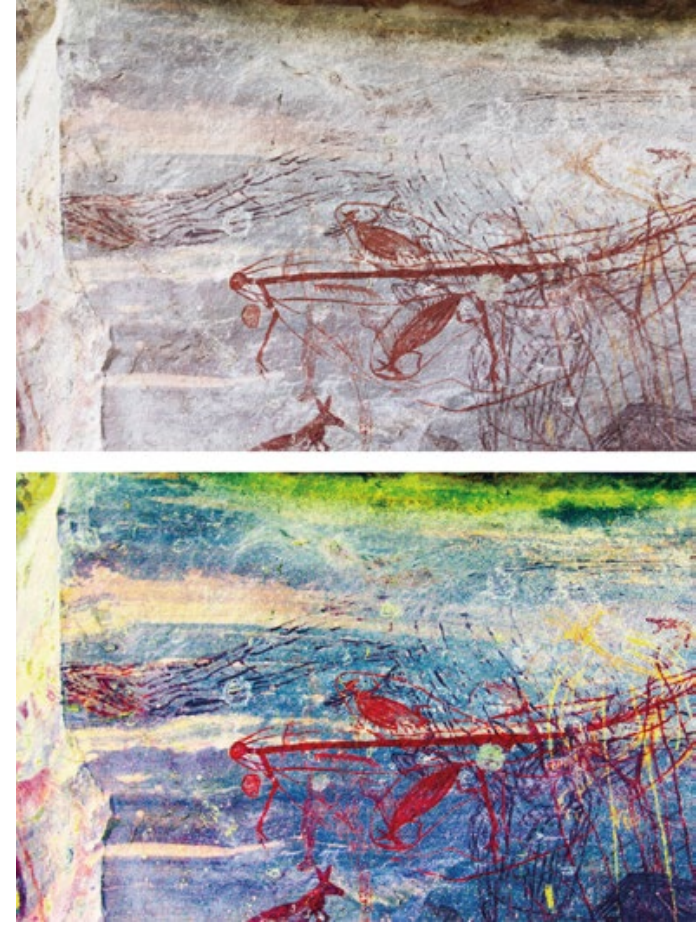

Figure 8.4 The thick tail structure of the kangaroo painted in Figure 8.3, which is unlike the tail of any modern animal and suggests the proportions required to balance the body of a large megafauna macropod. Top: Original image. Bottom: Enhanced image using DStretch.

Source: Photograph and enhancement by Steve Webb. 


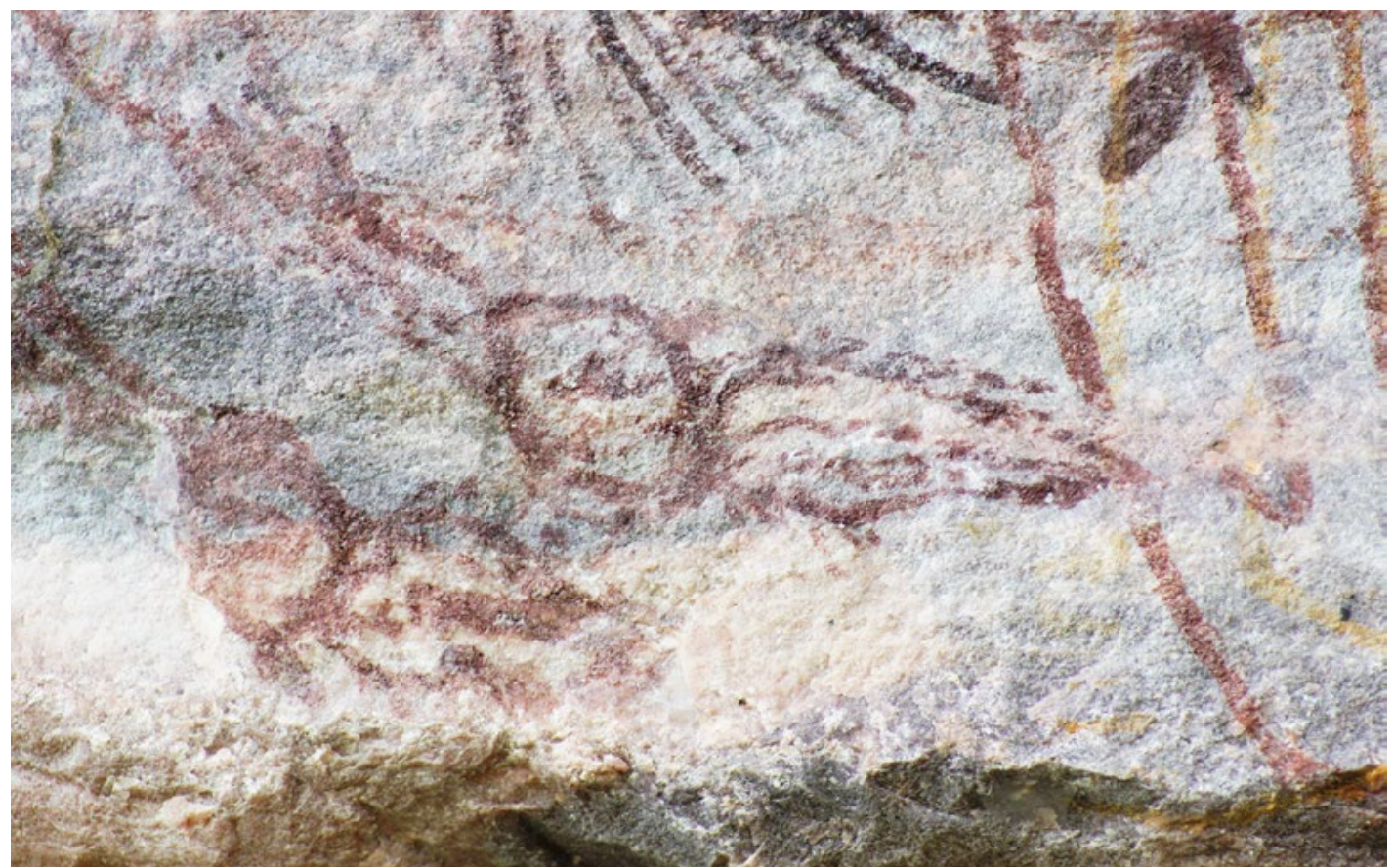

Figure $8.5 \mathrm{~A}$ close-up of the prominent single claw that is a distinct feature of the largest of shortfaced kangaroo Procoptodon goliah.

Source: Photograph by Steve Webb.
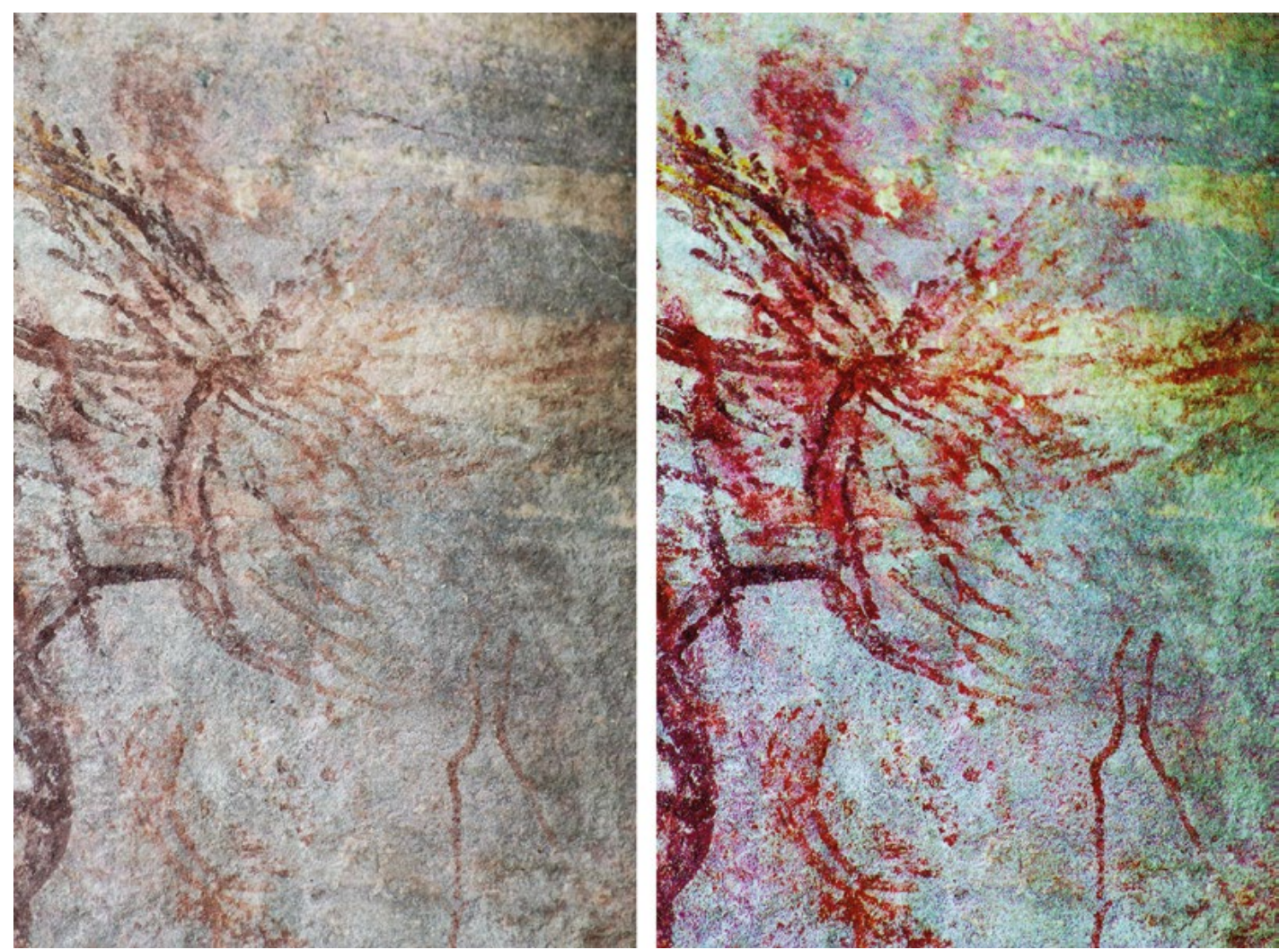

Figure 8.6 The distinct head region of the kangaroo in Figure 8.3 showing the rounded, shortened face structure and long hair on the ears. Left: Original image. Right: Enhanced image using DStretch. Source: Photograph and enhancement by Steve Webb. 
Features depicted in the above painting suggest a short-faced species of kangaroo. There were 23 short-faced kangaroo species, grouped in six genera, living in the mid to late Pleistocene in Greater Australia (Webb 2013) (Table 8.1). They include three species of Procoptodon, five (probable) 'Procoptodon', four Simosthenurus, four (probable) 'Simosthenurus', six Sthenurus and one Metasthenurus (Prideaux 2004). All were presumed extinct by the late Pleistocene, but a recent reassessment of the chronology of extinctions proposes that this timing was staggered, with seven short-faced species still around after humans arrived on the continent (Webb 2013; Wroe et al. 2013a). These surviving species include the largest short-faced species Procoptodon goliah (c. $250 \mathrm{~kg}$ ), the $150 \mathrm{~kg}$ 'Simosthenurus' pales, the $120 \mathrm{~kg}$ Simosthenurus occidentalis, 'Procoptodon' oreas (100 kg), Sthenurus andersoni $(75 \mathrm{~kg})$, 'Procoptodon' gilli and 'Procoptodon' browneorum (50-55 kg). Short-faced kangaroos lived widely across the south of the continent and in southeast Queensland, a distribution that does not preclude them from the Top End of the Northern Territory, particularly during glacial periods because at those times, environmental conditions were savannah-like in western Arnhem Land (Reeves et al. 2013). The short faces of these kangaroo species contrast with the long, slender, deer-like muzzles of modern and some extinct kangaroos. We propose that the painting in question is a short-faced species and a large animal given its bulky morphology and size. Any of the three largest extinct species listed above could be candidates for this image, although the presence of a prominent large claw suggests it might be Procoptodon goliah, as a large claw is a feature of this species.

Table 8.1 Listing of short-faced and long-faced kangaroos in the extinct megafauna cohort.

\begin{tabular}{|c|c|c|c|c|c|c|c|c|}
\hline Taxon & $\begin{array}{c}\text { Average } \\
\text { weight }(\mathrm{kg})\end{array}$ & QLD & NSW & VIC & LEB & SA & WA & TAS \\
\hline \multicolumn{9}{|l|}{ Short-faced kangaroos } \\
\hline 'Procoptodon' browneorum & 50 & $\checkmark$ & & $\checkmark$ & $\checkmark$ & $\checkmark$ & $\checkmark$ & \\
\hline 'Procoptodon' gilli & 54 & & $\checkmark$ & $\checkmark$ & $\checkmark$ & $\checkmark$ & $\sqrt{n}$ & \\
\hline 'Procoptodon' mccoyi & 50 & & & $S$ & & & & \\
\hline 'Procoptodon' oreas & 100 & $\checkmark$ & $\checkmark$ & & & $\checkmark$ & & \\
\hline 'Procoptodon' williamsi & 150 & & $\checkmark$ & & & $\checkmark$ & $\checkmark n$ & \\
\hline 'Simosthenurus' baileyi & 55 & & & & & $\checkmark$ & $\checkmark$ & \\
\hline 'Simosthenurus' brachyselenis & $>50$ & & $S$ & & & & & \\
\hline 'Simosthenurus' cf. antiquus & $>50$ & & & & & $S$ & & \\
\hline 'Simosthenurus' pales & 150 & $\checkmark$ & $\checkmark$ & & $\checkmark$ & $\checkmark$ & $\checkmark$ & \\
\hline Simosthenurus maddocki & 80 & $\checkmark$ & $\checkmark$ & $\checkmark$ & & $\checkmark$ & $\sqrt{n}$ & \\
\hline Simosthenurus occidentalis & 120 & & $\checkmark$ & $\checkmark$ & $\checkmark$ & $\checkmark$ & $\checkmark$ & $\checkmark$ \\
\hline Simosthenurus orientalis & $>50$ & $\checkmark$ & $\checkmark$ & & $\checkmark$ & $\checkmark$ & & $\checkmark$ \\
\hline Simosthenurus euryskaphus & $>50$ & & $S$ & & & & & \\
\hline Sthenurus agilis siva & $>50$ & $\checkmark$ & $\checkmark$ & & & $\checkmark$ & & \\
\hline Sthenurus andersoni & 72 & $\checkmark$ & $\checkmark$ & & $\checkmark$ & $\checkmark$ & $\checkmark n$ & $\checkmark$ \\
\hline Sthenurus atlas & 150 & $\checkmark$ & $\checkmark$ & $\checkmark$ & $\checkmark$ & $\checkmark$ & $\checkmark$ & \\
\hline Sthenurus murrayi & $>50$ & & $S$ & & & & & \\
\hline Sthenurus stirlingi & $>50$ & $\checkmark$ & & & $\checkmark$ & $\checkmark$ & & \\
\hline Sthenurus tindalei & 130 & $\checkmark$ & $\checkmark$ & $\checkmark$ & $\checkmark$ & $\checkmark$ & $\checkmark n$ & \\
\hline Metasthenurus newtonae & 55 & $\checkmark$ & $\checkmark$ & $\checkmark$ & & $\checkmark$ & $\checkmark$ & $\checkmark$ \\
\hline Procoptodon goliah & 230 & $\checkmark$ & $\checkmark$ & $\checkmark$ & $\checkmark$ & $\checkmark$ & $\checkmark n$ & \\
\hline Procoptodon pusio & 75 & $\checkmark$ & $\checkmark$ & & $\checkmark$ & & & \\
\hline Procoptodon rapha & 150 & $\checkmark$ & $\checkmark$ & $\checkmark$ & $\checkmark$ & $\checkmark$ & & \\
\hline Propleopus ocillans & 50 & $\checkmark$ & $\checkmark$ & $\checkmark$ & & $\checkmark$ & & \\
\hline
\end{tabular}




\begin{tabular}{|l|r|c|c|c|c|c|c|c|}
\hline Taxon & $\begin{array}{c}\text { Average } \\
\text { weight (kg) }\end{array}$ & QLD & NSW & VIC & LEB & SA & WA & TAS \\
\hline Long-faced kangaroos & 150 & & $\checkmark$ & & & $\checkmark$ & $\checkmark n$ & \\
\hline Macropus ferragus & 150 & $\checkmark$ & & & & & & \\
\hline Macropus pearsoni & 130 & $\checkmark$ & $\checkmark$ & $\checkmark$ & $\checkmark$ & $\checkmark$ & & $\checkmark$ \\
\hline Protemnodon anak & 110 & $\checkmark$ & $\checkmark$ & $\checkmark$ & $\checkmark$ & $\checkmark$ & $\checkmark$ & \\
\hline Protemnodon brehus & 170 & $\checkmark$ & & & & $\checkmark$ & $\checkmark n$ & \\
\hline Protemnodon roechus & $>50$ & $\checkmark$ & $\checkmark$ & $\checkmark$ & & & & \\
\hline Troposodon minor & $>50$ & & & $\checkmark$ & & & $\checkmark n$ & \\
\hline Baringa nelsonensis &
\end{tabular}

Black: Extant when humans lived in Australia. Underline: Extant until 51,000 years ago. Grey: Extant until the last interglacial (126,000 years ago). LEB stands for Lake Eyre Basin. ' $s$ ' means only a single species has ever been found. The ' $n$ ' means the species was found on the Nullarbor Plain or to the east, but not in the southwest of Western Australia. Note that no remains have been found in the Northern Territory.

Source: Steve Webb.

\section{Protemnodon in Arnhem Land?}

Another large macropod painting occurs in the Wellington Range, less than a kilometre from the Djulirri Thylacoleo-like painting discussed above. The painting shows a kangaroo bending over and measuring $251 \mathrm{~cm}$ wide and $146 \mathrm{~cm}$ high from the bottom of its left foot to the top of its bent back (Figures 8.7). The head is in profile with ears extending onto the shelter's ceiling (Figure 8.8). The side of the head is $40 \mathrm{~cm}$ in length and $10 \mathrm{~cm}$ wide at the muzzle, and there are huge ears spread over $38 \mathrm{~cm}$ (the left ear is $22 \mathrm{~cm}$ long). This is one of the largest macropod heads recorded in Arnhem Land. The tail is $75 \mathrm{~cm}$ long and $20 \mathrm{~cm}$ wide, much broader than for any extant species (Figure 8.9). The hind feet are very large, with the right foot measuring $40 \mathrm{~cm}$ long and a maximum width of $14 \mathrm{~cm}$ (Figure 8.10). The front feet are depicted with huge pointed claws (Figure 8.11). Other nearby paintings of extant species in the same style have essentially correct body proportions, so we assume that this is also true of this macropod painting. Exactly which species it represents is uncertain, but a very large animal with a longer face may be one of three Protemnodon species that weighed between 110-170 kg, all believed to be extant when humans arrived.

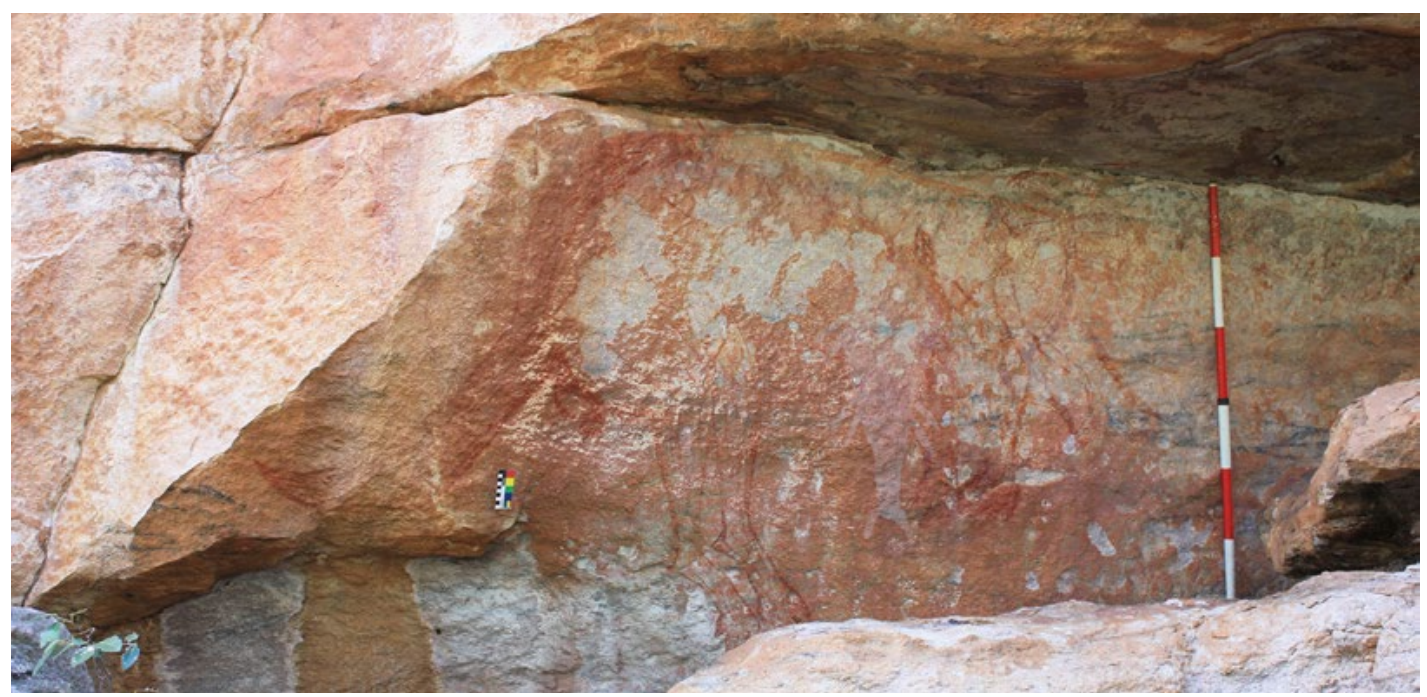

Figure 8.7 A large kangaroo that is a possible representation of Protemnodon(?), painted in the Wellington Range northeast of the Kakadu painting.

Source: Photograph by Paul S.C. Taçon. 

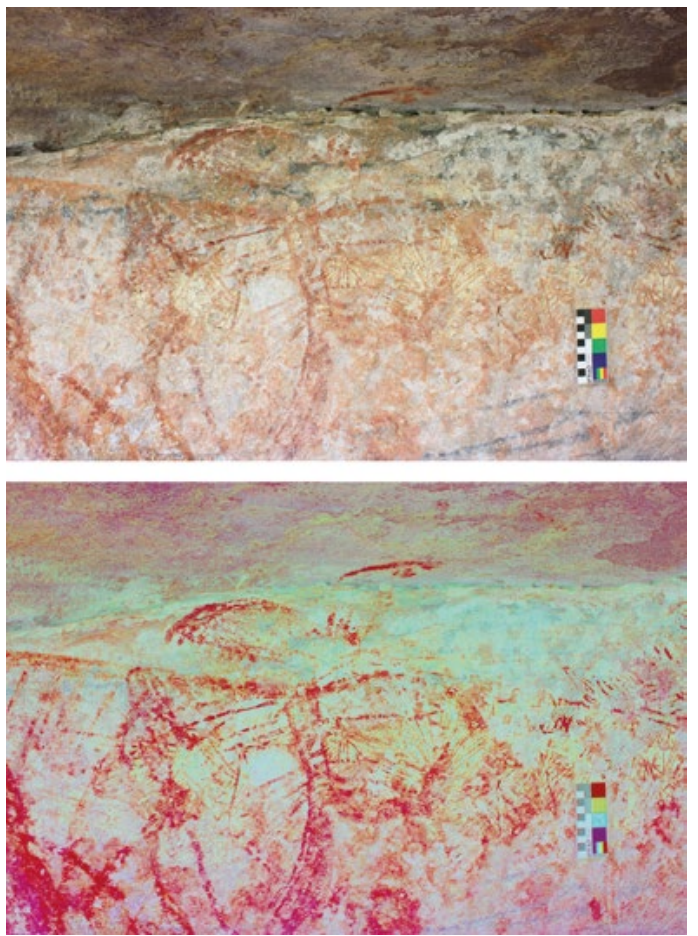

Figure 8.8 This animal has a longer face than the Kakadu kangaroo, and other features that might represent one of the long-faced extinct varieties, such as Protemnodon of which there were three species, all believed to exist until after humans arrived (Table 8.1; see also Figure 8.3). Top: Original image. Bottom: Enhanced image using DStretch. Scale $10 \mathrm{~cm}$.

Source: Photograph and enhancement by Paul S.C. Taçon.

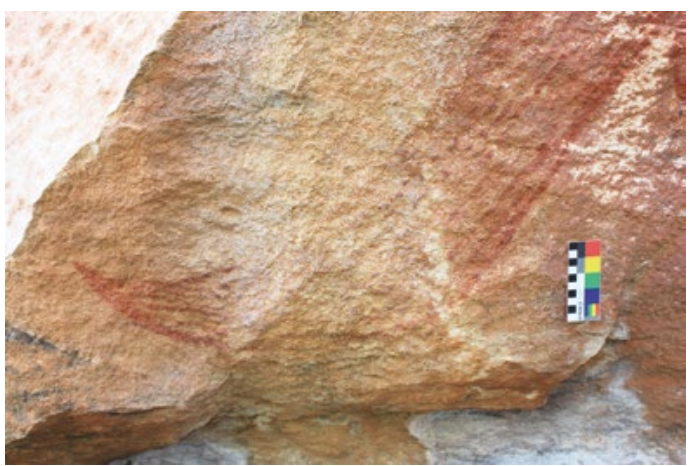

Figure 8.9 The tail is very broad, up to $20 \mathrm{~cm}$ wide, and much broader than any extant kangaroo. Scale $10 \mathrm{~cm}$.

Source: Photograph by Paul S.C. Taçon.

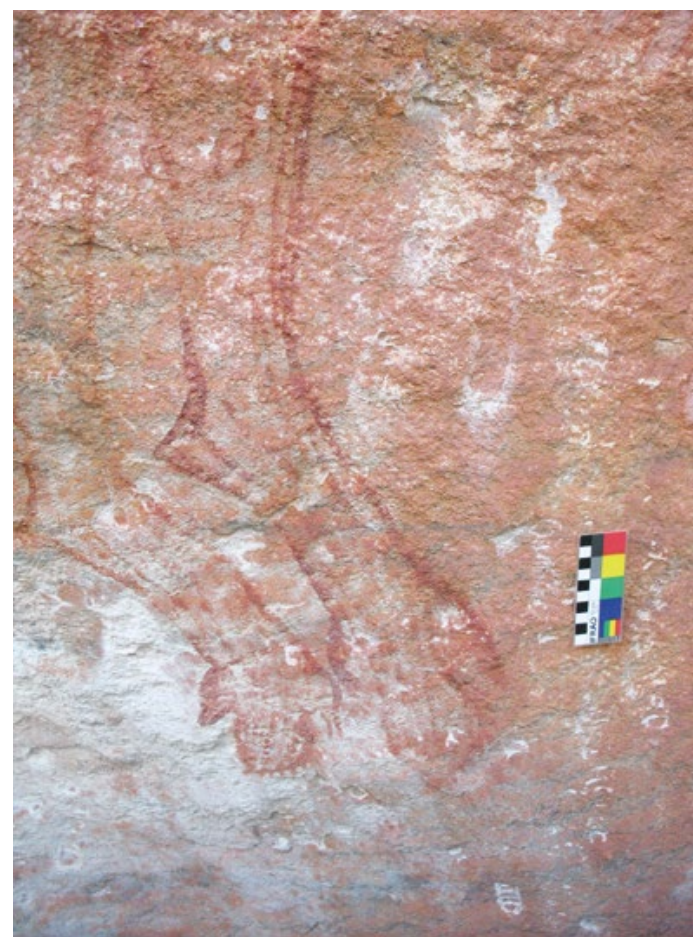

Figure $8.10 \mathrm{~A}$ close up of the feet of the large kangaroo (Protemnodon?). These feet are quite different from those of the image depicted in Figure 8.5. They are much broader, shorter and show a distinct paw-like morphology absent from the animal in Figure 8.5 . Scale $10 \mathrm{~cm}$.

Source: Photograph by Paul S.C. Taçon.

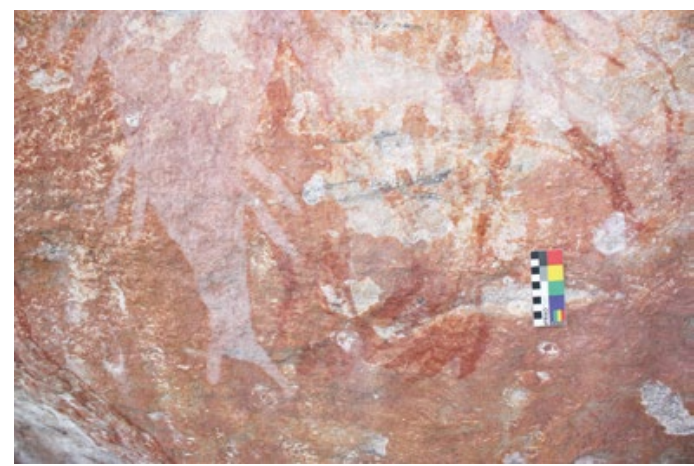

Figure 8.11 The front feet are shown with huge pointed claws. Scale $10 \mathrm{~cm}$.

Source: Photograph by Paul S.C. Taçon. 


\section{Genyornis in Arnhem Land?}

The image of a large bird underlying the shortfaced kangaroo on the Ubirr panel shows a bulky body covered with coarse feathers painted redbrown but lacking wings and legs. The short neck is painted in a much lighter colour, possibly indicating different plumage types and/or colour from the rest of the body (Figure 8.12). At a glance, this painting could be taken for an emu (Dromaius novaehollandiae), a species currently extant in the region. But the neck in the painting is shorter and the head is smaller and differently shaped to those of an emu. Moreover, in the painting, the prominent beak is broad, flat and long like a goose rather than the short, narrow design of an emu. Overall, the appearance is identified as an unknown type of flightless bird that is strongly underpinned by the bulky body shape. Is it a Genyornis, which also had a goose-like beak and solid body? The painting's appearance is unlike another image reported from southern Arnhem Land and believed by some researchers to be Genyornis (Gunn et al. 2011; but see Bednarik 2013a; see also Chapter 15, this volume), or of another from far north Queensland also thought by some to be of that genus (Trezise 1971). It is possible that sexual dimorphism or stage of maturity in Genyornis may account for the somewhat different appearances of apparent Genyornis paintings, but this is speculation. There could also be one more possibility: that there were several species of Genyornis, similar to the situation in New Zealand Moas of which there were nine species in six genera. What we can say is that the new image we report here is of a large, unknown, probably flightless bird of a ratite or dromornithid origin.

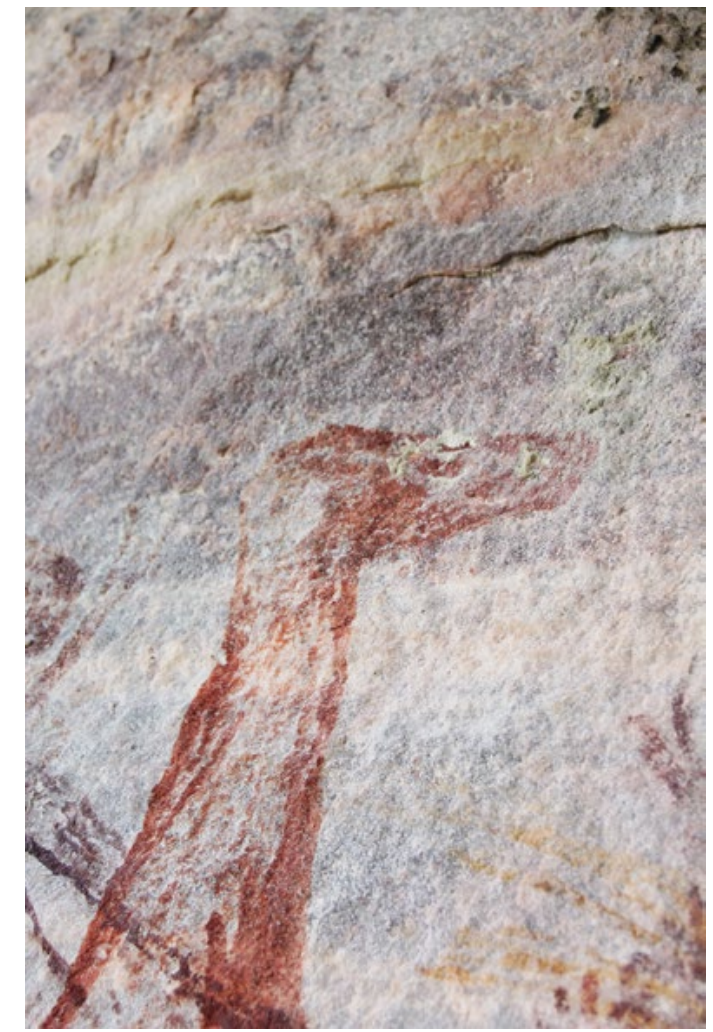

Figure 8.12 The unidentified 'flightless' bird that underlies the large short-faced kangaroo.

Source: Photograph by Steve Webb.

\section{How should we interpret these enigmatic images?}

Unknown animals in rock art could be dismissed as depictions of Ancestral Beings or spirit animals that are the products of cultural belief, imagination and creativity. The naturalistic images discussed here, however, are difficult to explain in that way. In some respects, these images parallel extinct fauna represented in Europe's Upper Palaeolithic cave art (e.g. woolly mammoths and rhinoceroses at Rouffignac, Chauvet Cave and elsewhere) and recently discovered engravings of 'mammoths' in North America (Clottes 2013; Molatki and Wallace 2011; but see Bednarik 2013b). In such a reading, the paintings discussed above are depictions of animals familiar to the artist, whatever the exact reason for their placement on the rock surface. As in the European and 
North American depictions, the Arnhem Land artists have painted readily identified animal forms that seemingly indicate known species of megafauna. Furthermore, spiritual or mythical beings and creatures in Aboriginal art are normally identified by their exaggerated or abstract forms and associated features that little resemble everyday creatures, with the most powerful often having a composite form made up of body parts of various animals (Taçon and Chippindale 2000; Taçon et al. 1996). In some of the relatively recent art of western Arnhem Land, and to a lesser extent the Kimberley and Pilbara regions, naturalism is evident not only in paintings of terrestrial and aquatic wildlife of the everyday world, but also in recent times of non-Aboriginal objects such as European ships, Macassan prau, aircraft, firearms and other objects (e.g. Chaloupka 1993; May et al. 2010; Wesley 2013). Such naturalistic imagery is easily recognisable and can often be identified to particular animal taxa or object types and makes.

Western Arnhem Land Aboriginal artists of the recent past as well as of more ancient times paint excellent and detailed likenesses of extant animals they live with, which can often be identified to species level by Western researchers and local Aboriginal people alike (Chaloupka 1993; Taçon 1988), just as has been done for European Upper Palaeolithic paintings of animals. If the images described above do show long-extinct species of megafauna, the question that then arises is when were they painted? If final extinction of the last megafauna took place c. 40,000-50,000 years ago (e.g. Miller et al. 1999), these paintings would pre-date the known age of naturalistic art of any fauna, extinct or not, anywhere in the world. On the other hand, if the Arnhem Land images are those of extinct megafauna - as they may well be - then it is also possible that these animals survived in Arnhem Land longer (see also Webb 2013; Wroe et al. 2013). Consistent with this latter interpretation, new rock art dating results are showing that rock paintings can survive at least 40,000 years (Aubert et al. 2014; Pike et al. 2012; Sadier et al. 2012), and there is probably much older rock art that has not yet been reliably dated.

All of the new discoveries reported here follow the earliest 'Large Naturalistic Animal' painting practice that underlies all other figurative styles in Arnhem Land and is argued to be Pleistocene in age (e.g. see Chaloupka 1993; Chippindale and Taçon 1993, 1998; Lewis 1988; Taçon and Brockwell 1995; a good example is in Taçon et al. 2011, but see Taçon and Chippindale 2008 for discussion of more recent [mid-Holocene] naturalistic animal paintings). In this regard, new dating results from rock art sites in Sulawesi to Australia's immediate north support the idea that extremely old rock art likely survives in the Greater Australian region. Uranium-series dating of speleothems over and under 12 hand stencils and two naturalistic animal depictions from seven sites in the Maros area of Sulawesi, on Greater Australia's northern doorstep, has revealed the oldest ages for these forms of rock art in the world. The earliest minimum age for a hand stencil is 39,900 years at Leang Timpuseng and the oldest animal painting, of a babirusa 'pigdeer' at the same site, is 35,400 years. A second animal painting (probably a pig) at another site has a minimum age of 35,700 years (Aubert et al. 2014). There are many other naturalistic animal paintings not yet dated, painted in ways reminiscent of some of the earliest rock art of the Kimberley and Kakadu/Arnhem Land region where hand stencils also appear early in local chronologies based on superimpositions. The Sulawesi paintings mostly survive in rockshelters, rather than in deep caves as in Europe. Aubert et al.'s (2014) research thus signals that it is conceivable that similarly old art survives in northern Australia and that the early art of both Sulawesi and northern Australia may have resulted from a shared practice undertaken by modern humans as they spread across the region (Aubert et al. 2014; Taçon et al. 2014). 


\section{Conclusion}

Unfortunately, little rock art in Arnhem Land has been scientifically dated, especially images argued to be the oldest, and we do not have minimum or maximum ages for large naturalistic paintings near the beginning of the Arnhem Land sequence, including what may be depictions of megafauna. Consequently, we can only rely on morphology as conveyed by artists in their paintings for identifying possible depictions of megafauna. Size is also important in that early depictions of extant and more easily identifiable fauna are usually at or near life-size, but size alone cannot be used as a criteria for identifying megafauna (Bednarik 2013a). And an important difference between Australia and Europe in terms of depictions of extinct megafauna is that in Europe there are multiple repetitions, while in Australia there are isolated finds or small numbers at sites. This may partly be a preservation and/or survey issue, and there may be other factors that influenced the frequency of megafauna depictions.

However, we have shown that there are sound grounds to support the argument that there are surviving Pleistocene depictions of megafauna at rock art sites in northern Australia (in particular, the two giant kangaroo paintings discussed above), based on 1) the naturalistic appearance of the animal images, 2) comparability with what is known from the fossil record to the south, and 3) new knowledge about the long-term survivability of rock paintings in the Greater Australian island Southeast Asian region (cf. Aubert et al. 2014). The new Arnhem Land rock art depictions interpreted as megafauna are important in that the paintings show the existence of probable megafauna species in the far north of the continent, a place at the forefront of human arrivals into Greater Australia. If they are indeed depictions of extinct megafauna, these paintings also show overlap with humans: humans encountered these creatures and made images of them. In an area where fossil bone preservation and/or visibility seem to be absent, we may now have the beginning of a record, albeit tentative, limited in terms of species and open to debate.

New and innovative dating programs are needed to ascertain the age of the paintings described here, because the dating of paintings in sandstone shelters is far less advanced than it is for limestone shelters where the oldest rock art of Indonesia and Europe are found. The oldest ages for the presence of humans in Australia, at least 65,000 years ago by optically stimulated luminescence dating, are derived from the Madjedbebe (Malakunanja II) rockshelter, located within the area where the apparent Arnhem Land megafauna paintings are found (Clarkson et al. 2017; Roberts et al. 1998). Even if some researchers are correct that most species of megafauna became extinct about 40,000-50,000 years ago, the Madjedbebe dates show that humans and megafauna probably co-existed for thousands of years in the Kakadu/Arnhem Land region. There may also have been a slow, climatically driven process of megafaunal attrition throughout the mid to late Pleistocene, as Wroe et al. (2013a, 2013b) and Webb (2013) have argued. Whatever the case, there was time for Australia's early inhabitants to record megafauna in north Australian rockshelters before they disappeared forever. The images described here appear to give us a unique window into aspects of what Australia looked like when humans first arrived. Advances in dating both megafaunal remains and rock art, as well as new discoveries, will allow us to better support or refute arguments about some of the unusual, seemingly ancient imagery described here.

\section{Acknowledgements}

Griffith University and Bond University supported this research. We thank Gabrielle O'Loughlin and other Kakadu National Parks staff as well as members of the Gunbalanya Community and Traditional Owners for facilitating access to the Kakadu site. The Northern Land Council, 
Ronald Lamilami and other Namunidjbuk Estate Traditional Owners are thanked for access and permission to record the Wellington Range sites. Wellington Range research was the result of Australian Research Council Discovery grant DP080877463.

\section{References}

Akerman, K. 1998. A rock painting, possibly of the now extinct marsupial Thylacoleo (marsupial lion), from the north Kimberley, Western Australia. The Beagle, Records of the Museum and Art Gallery of the Northern Territory 14:117-121.

Akerman, K. 2009. Interaction between humans and megafauna depicted in Australian rock art? Antiquity 83(322). www.antiquity.ac.uk/projgall/akerman322/

Akerman, K. and T. Willing 2009. An ancient rock painting of a marsupial lion, Thylacoleo carnifex, from the Kimberley, Western Australia. Antiquity 83(319). antiquity.ac.uk/projgall/akerman319/

Archer, M. 1974. New information about the Quaternary distribution of the thylacine (Marsupialia, Thylacinidae) in Australia. Journal of the Royal Society of Western Australia 57:43-49.

Aubert, M., A. Brumm, R. Ramli, T. Sutikna, E.W. Saptomo, B. Hakim, M.J. Morwood, G.D. van den Berg, L. Kinsley and A. Dosseto 2014. Pleistocene cave art from Sulawesi, Indonesia. Nature 524:223-227. doi.org/10.1038/nature13422

Basedow, H. 1925. The Australian Aboriginal. F.W. Preece and Sons, Adelaide.

Bednarik, R.G. 2013a. Megafauna depictions in Australian rock art. Rock Art Research 30(2):197-215.

Bednarik, R.G. 2013b. Proboscidean petroglyphs in the USA. INORA 67:1-7.

Brandl, E. 1972. Thylacine designs in Arnhem Land rock paintings. Archaeology and Physical Anthropology in Oceania 7(1):24-30.

Brook, B.W., C.J.A. Bradshaw, A. Cooper, C.N. Johnson, T.H. Worthy, M. Bird, R. Gillespie and R.G. Roberts 2013. Lack of chronological support for stepwise prehuman extinctions of Australian megafauna. Proceedings of the National Academy of Sciences (PNAS) 110(36):E3368. doi.org/10.1073/ pnas. 1309226110

Brown, O. 2006. Tasmanian devil (Sarcophilus harrisii) extinction on the Australian mainland in the mid-Holocene: Multicausality and ENSO intensification. Alcheringa: An Australasian Journal of Paleontology 30(1): 49-57. doi.org/10.1080/03115510609506855

Cane, S. 2013. First footprints: The epic story of the First Australians. Allen and Unwin, Crows Nest.

Chaloupka, G. 1993. Journey in Time: The World's Longest Continuing Art Tradition. Reed, Chatswood.

Chippindale, C. and P.S.C. Taçon 1993. Two old painted panels from Kakadu: Variation and sequence in Arnhem Land rock art. In J. Steinbring, A. Watchman, P. Faulstich and P.S.C. Taçon (eds), Time and Space: Dating and Spatial Considerations in Rock Art Research, pp. 32-56. Occasional AURA Publication 8. Australian Rock Art Research Association, Melbourne.

Chippindale, C. and P.S.C. Taçon 1998. The many ways of dating Arnhem Land rock-art, north Australia. In C. Chippindale and P.S.C. Taçon (eds), The Archaeology of Rock-Art, pp. 90-111. Cambridge University Press, Cambridge. 
Clarkson, C., Z. Jacobs, B. Marwick, R. Fullagar, L. Wallis, M. Smith, R.G. Roberts, E. Hayes, K. Lowe, X. Carah, S.A. Florin, J. McNeil, D. Cox, L. J. Arnold, Q. Hua, J. Huntley, H.E.A. Brand, T. Manne, A. Fairbairn, J. Shulmeister, L. Lyle, M. Salinas, M. Page, K. Connell, G. Park, K. Norman, T. Murphy and C. Pardoe 2017. Human occupation of Australia by 65,000 years. Nature 547(7663): 306-310. doi.org/10.1038/nature22968

Clegg, J. 1978. Pictures of striped animals: Which ones are thylacines? Archaeology and Physical Anthropology in Oceania 13(1)19-29.

Clottes, J. 2013. Two petroglyphs of Proboscideans at Upper Sand Island, Bluff, Utah (USA). INORA 67:7-10.

Gollan, K. 1984. The Australian dingo: In the shadow of man. In M. Archer, M. and G. Clayton (eds), Vertebrate Zoogeography and Evolution in Australia, pp. 921-927. Hesperian Press, Perth.

Gunn, R.G., Douglas, L.C. and R.L. Wear 2011. What bird is that? Identifying a probable painting of Genyornis newtoni in Western Arnhem Land. Australian Archaeology 73:1-12.

Johnson, C.N. 2006. Australia's Mammal Extinctions: A 50,000 Year History. Cambridge University Press, Melbourne.

Lewis, D.J. 1977. More striped designs in Arnhem Land rock paintings. Archaeology and Physical Anthropology in Oceania 12(2):98-111.

Lewis, D.J. 1988. The Rock Paintings of Arnhem Land, Australia: Social, Ecological and Material Culture Change in the Post-Glacial Period. BAR International Series 415. British Archaeological Reports, Oxford.

Lewis, D.J. 2017. Megafauna identification for dummies: Arnhem Land and Kimberley 'Megafauna' paintings. Rock Art Research 34(1): 82-99.

May, S.K., P.S.C. Taçon, D. Wesley and M. Pearson 2013. Painted ships on a painted Arnhem Land landscape. The Great Circle 35(2):83-102.

May, S.K., P.S.C. Taçon, D. Wesley and M. Travers 2010. Painting history: Indigenous observations and depictions of the 'other' in northwestern Arnhem Land, Australia. Australian Archaeology 71:57-65. doi.org/10.1080/03122417.2010.11689384

Miller, G.H., J. Magee, B.J. Johnson, M.L. Fogel, N.A. Spooner, M.T. McCulloch and L. Ayliffe 1999. Pleistocene extinction of Genyornis newtoni: Human impact on Australian megafauna. Science 283:205-208. doi.org/10.1126/science.283.5399.205

Molatki, E. and H.D. Wallace 2011. Columbian mammoth petroglyphs from the San Juan River near Bluff, Utah, United States. Rock Art Research 28(2):143-152.

Mulvaney, K. 2009. Dating the Dreaming: Extinct fauna in the petroglyphs of the Pilbara region, Western Australia. Archaeology in Oceania 44 Supplement: 40-48. doi.org/10.1002/j.18344453.2009.tb00067.x

Mulvaney, K. 2013. Iconic imagery: Pleistocene rock art development across northern Australia. Quaternary International 285:99-110. doi.org/10.1016/j.quaint.2011.07.020

Murray, P. and G. Chaloupka 1984. The Dreamtime animals: Extinct megafauna in Arnhem Land rock art. Archaeology in Oceania 19:106-116. doi.org/10.1002/j.1834-4453.1984.tb00089.x

Ouzman, S., P.S.C. Taçon, K. Mulvaney and R. Fullagar 2002. Extraordinary engraved bird track from North Australia: Extinct fauna, Dreamtime Being or aesthetic masterpiece? Cambridge Archaeological Journal 12(1):103-112. doi.org/10.1017/S0959774302000057 
Pike, A.W.G., D.L. Hoffman, M. García-Diez, P. Pettitt, J. Alcolea, R. De Balbín, C. González-Sainz, C. de las Heras, J.A. Lasheras, R. Montes, R. and J. Zilhão 2012. U-series dating of Paleolithic art in 11 caves in Spain. Science 336, 1409-1413.

Prideaux, G.J. 2004. Systematics and evolution of the sthenurine kangaroos. University of California Publications in Geological Sciences Volume 146: pp.1-623. University of Chicago Press, Berkley. doi.org/10.1525/california/9780520098459.001.0001

Reeves, J.M., H.C. Bostock, L.K. Ayliffe, T.T. Barrows, P. De Deckker, L.S. Devriendt, G.B. Dunbar, R.N. Drysdale, K.E. Fitzsimmons, M.K. Gagan, M.L. Griffiths, S.G. Haberle, J.D. Jansen, C. Krause, S. Lewis, H.V. McGregor, S.D. Mooney, P. Moss, G.C. Nanson, A. Purcell and S. Van der Kaars 2013. Palaeoenvironmental change in tropical Australasia over the last 30,000 years - a synthesis by the OZ-INTIMATE group. Quaternary Science Reviews. doi.org/10.1016/j. quascirev.2012.11.027

Roberts, R.G., H. Yoshida, R. Galbraith, G. Laslett, R. Jones and M. Smith 1998. Single-aliquote and single-grain optical dating confirm thermoluminescence age estimates at Malakunanja II rock shelter in northern Australia. Ancient TL 16:19-24.

Roberts, R.G., T.F. Flannery, L.K. Ayliffe, H. Yoshida, J.M. Olley, G.J. Prideaux, G.M. Laslett, A. Baynes, A., Smith, M.A., Jones, R. and B.L. Smith 2001. New ages for the last Australian megafauna: Continent-wide extinction 46,000 years ago. Science 29:1888-1892.

Sadier, B., J.-J. Delannoy, L. Benedetti, D.L., Bourlès, S. Jaillet, J.-M.Geneste, A.-E Lebatard and M. Arnold 2012. Further constraints on the Chauvet cave artwork elaboration. Proceedings of the National Academy of Sciences (PNAS) 109(21), 8002-8006.

Taçon, P.S.C. 1988. Identifying fish species in the recent rock paintings of western Arnhem Land. Rock Art Research 5(1):3-15.

Taçon, P.S.C. 2011. Special places and images on rock; 50,000 years of Indigenous engagement with Australian landscapes. In J. Anderson (ed.), Cambridge Companion to Australian Art, pp. 11-21. Cambridge University Press, Melbourne.

Taçon, P.S.C. and S. Brockwell 1995. Arnhem Land prehistory in landscape, stone and paint. Antiquity 69(259):676-95. doi.org/10.1017/S0003598X00082272

Taçon, P.S.C. and C. Chippindale 2000. Transformation and depictions of the First People: Animalheaded beings of Arnhem Land, N.T., Australia. In K. Helskog (ed.), Theoretical Perspectives in Rock Art Research, pp. 175-210. Novus Forlag, Oslo.

Taçon, P.S.C. and C. Chippindale 2008. Changing places: Ten thousand years of north Australian rock-art transformation. In D. Papagianni, H. Maschner and R. Layton (eds), Time and Change: Archaeological and Anthropological Perspectives on the Long-Term in Hunter-Gatherer Societies, pp. 73-94. Oxbow Books, Oxford.

Taçon, P.S.C., W. Brennan and R. Lamilami 2011. Rare and curious thylacine depictions from Wollemi National Park, New South Wales and Arnhem Land, Northern Territory, Australia. In J. Specht and R. Torrence (eds), Changing Perspectives in Australian Archaeology. Technical Reports of the Australian Museum online Volume 23, Issue 11, pp. 165-174. The Australian Museum, Sydney. doi.org/10.385 3/j.1835-4211.23.2011.1576

Taçon, P.S.C., M. Wilson and C. Chippindale 1996. Birth of the Rainbow Serpent in Arnhem Land rock art and oral history. Archaeology in Oceania 31(3):103-124. doi.org/10.1002/j.1834-4453.1996. tb00355.x 
Taçon, P.S.C., N.H. Tan, S. O’Connor, X. Ji, L. Gang, D. Curnoe, D. Bulbeck, B. Hakim, I. Sumantri, H. Than, I. Sokrithy, S. Chia, K. Khun-Neay and S. Kong 2014. Global implications of early surviving rock art of greater Southeast Asia. Antiquity 88:1050-1064. doi.org/10.1017/ S0003598X00115315

Trezise, P. 1971. Rock Art of South-East Cape York. Australian Institute of Aboriginal Studies, Canberra.

Walsh, G. 2000. Bradshaw Art of the Kimberley. Takarakka Nowan Kas Publications, Toowong, Queensland, Australia.

Webb, S. 2008. Megafauna demography and late Quaternary climatic change in Australia: A predisposition to extinction. Boreas 39:25-38. doi.org/10.1111/j.1502-3885.2008.00026.x

Webb, S. 2013. Corridors to Extinction and the Australian Megafauna. Elsevier, New York.

Welch, D. 2015. Thy Thylacoleo is a thylacine. Australian Archaeology 80(1):40-47. doi.org/10.1080/031 22417.2015.11682043

Welch, D. and A. Welch. 2015. Palorchestes or bunyip? International Newsletter on Rock Art 72: 18-24.

Wesley, D. 2013. Firearms in rock art of Arnhem Land, Northern Territory, Australia. Rock Art Research 30(2): 235-247.

Wright, B.J. 1972. Rock engravings of striped mammals: the Pilbara region, Western Australia. Archaeology and Physical Anthropology in Oceania 7(1):15-23.

Wroe, S. and J. Field 2006. A review of the evidence for a human role in the extinction of Australian megafauna and an alternative interpretation. Quaternary Science Review 25(21-22):2692-2703. doi. org/10.1016/j.quascirev.2006.03.005

Wroe, S., J.H. Field and D.K. Grayson 2006. Megafaunal extinction: Climate, humans and assumptions. Trends in Ecological Evolution 21(2):61-62. doi.org/10.1016/j.tree.2005.11.012

Wroe, S., J. Field, R. Fullagar and L.S. Jermiin 2004. Megafaunal extinction in the late Quaternary and the global overkill hypothesis. Alcheringa 28(1):291-331. doi.org/10.1080/03115510408619286

Wroe, S., J.H. Field, M. Archer, D.K. Grayson, G.J. Price, J. Louys, T. Faith, T., G.E. Webb, I. Davidson and S.D. Mooney 2013a. Climate change frames debate over the extinction of megafauna in Sahul Pleistocene Australia-New Guinea. Proceedings of the National Academy of Sciences (PNAS) 110(22):8777-9781.

Wroe, S., J.H. Field, M. Archer, G.K. Grayson, G.J. Price, J. Louys, J.T Faith, G.E. Webb, I. Davidson and S.D. Mooney 2013b. Reply to Brook et al: No empirical evidence for human overkill of megafauna in Sahul. Proceedings of the National Academy of Sciences (PNAS) 110(36):E3369. doi.org/ $10.1073 /$ pnas. 1310440110 
This text is taken from The Archaeology of Rock Art in Western Arnhem Land, Australia, edited by Bruno David, Paul Taçon, Jean-Jacques Delannoy and Jean-Michel Geneste, published 2017 by ANU Press, The Australian National University, Canberra, Australia. 